\title{
Nasie, volk, religie en die kerk as ellips van versoenende verskeidenheid
}

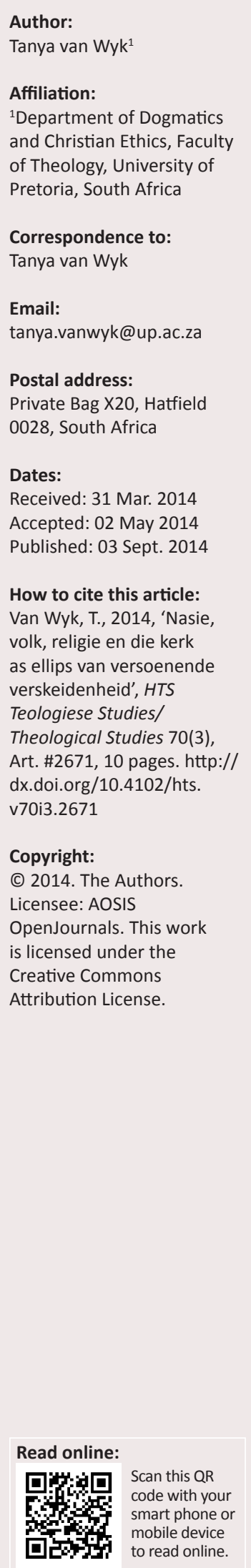

Nation, 'ethnic people' (das Volk), religion and the church as ellipse of reconciling diversity. This article examines the 19th and 20th century European context wherein religion was practiced. In a 'Rip-Van-Winkle' manner it is as if this context had no influence on the Afrikaans speaking church in South Africa. The isolation, that was the result of the apartheid ideology, lead to the Afrikaans speaking church in South Africa not internalising ecumenicity. It is argued that for the church to be able to take an active role in reconciling diversity and therefore contributing to social cohesion in South Africa, the church needs to transcend being a 'nation' church. This is possible by respecting culture and diversity, while recognising the priority of salvation in Christ. This is the ellipse of being church.

\section{Inleiding}

\section{'n Onvoltooide paradigmaskuif: Die verhouding Europa-Suid-Afrika as 'prolepsis', 'analepsis' en 'ellipsis'}

'n Verhaal het altyd meer as een storielyn. Die literatuurteoretikus Eberhard Lämmert ([1955] 1972) wys daarop dat in narratief-diskursiewe materiaal daar dikwels meerdere verhaallyne (Handlungsstränge) kan voorkom. Waar dit gebeur is dit belangrik om die verband te bepaal. Elke verhaallyn vorm 'n Handlungsstrang en die kombinasie van die verhaallyne vorm 'n Rahmenhandlung. Een van die verhaallyne funksioneer as die dominante (übergeordnete Handlung) en die ander verhaallyne is daaraan ondergeskik (eingelagerte Handlungsstränge). Die aard van die verband tussen dié wat domineer en dié wat ondergeskik is, staan bekend as die 'knooppunt' (Verknüpfungsprinzip) (kyk Lämmert [1955] 1972:21).

Hierdie 'prinsiepe' kan ook oorgedra word op die lewe as 'n diskoers - van 'n individu of 'n groep. Die raakpunte tussen die verhaallyne ('jukstaposisie') kan soms enkelvoudig wees en soms gekompliseerd. In die 'lewe as die diskoers' is dit gewoonlik altyd kompleks. Die opeenvolging tussen moderniteit en postmoderniteit is byvoorbeeld nie net eenvoudig ' $n$ oorgang tussen industrialisasie en postindustrialisasie nie. Hierdie twee epogge het immers te doen met die lewensomstandighede van mense: hulle kleinnarratiewe (eingelagerte Handlungstränge) is beslissend bepaal deur meesternarratiewe (übergeordnete Handlung). Kerk-wees word ook deur sulke prosesse beïnvloed. In die narratief-diskursiewe teorie van Gerárd Genette ([1972] 1980:113-160) word terme soos 'prolepsis', 'analepsis' en 'ellipsis' gebruik om die kompleksiteit van die verhouding tussen meerdere verhaallyne te beskryf. Hierdie kompleksiteit kan selfs in 'n enkele verhaallyn (lewensvertelling van 'n individu of groep) voorkom. So byvoorbeeld kan die eerste jare van 'n individu (of die geskiedenis van 'n groep soos ' $n$ kerk) die intrige en selfs die lotgeval van die latere jare antisipeer (dit wil sê die een is 'n 'prolepsis' van die ander). Dit is ook moontlik dat 'n vroeëre verhaal (byvoorbeeld vanuit die voorgeslagte, of 'n vorige periode) 'n 'prolepsis' vorm van 'n nuwe, heersende verhaal waarvan die intrige daarvan nie sonder die vorige kragte na behore verstaan kan word nie. De-kolonialisering in die Derde Wêreld is 'n komplekse aangeleentheid wat verband hou met die ineenstorting van die vermoë van vroeëre koloniale moondhede. Die ontwaking en waardering van die regte van individue en groepe volg dikwels op 'n vorige periode waar maghebbers met behulp van meesternarratiewe 'ondergeskiktes' gemarginaliseer het - en dit kan ouderdom, ras, seksuele oriëntasie of gender raak. Verklarings oor menseregte, gekodeer in grondwette, of gemenereg, is by wyse van terugskoue ('analepsis') die produkte van revolusies.

Wanneer die logiese opeenvolging van een narratief na 'n ander narratief, wat mense in bepaalde kontekste beïnvloed, ander mense in die kontemporêre tyd onaangeraak laat, ontstaan ' $n$ 'ellipsis' in die narratief (vgl. Van Wyk 2013a:8). Die bekende verhaal van die karakter 'Rip van Winkel' is 'n voorbeeld hiervan. In sy Vertelkunde, verduidelik André P. Brink (1987) hierdie ingewikkelde distorsie in tyd soos volg: 
'n Kenmerkende verhaalprosedure is om 'n gebeurereeks te skep van insidente wat in die tyd saamhoort (byvoorbeeld in één dag), daarna oor 'n hele stuk tydsverloop te spring waarin niks 'gebeur' wat vir die storie ter sake is nie [wat relevant vir die lewensnarratief behoort te wees]. (bl. 62, [my beklemtoning])

Die Tweede Wêreldoorlog, 'analepties' reeds geantisipeer in die Eerste Wêreldoorlog, het 'n belangrike invloed uitgeoefen op die perspektiewe in die ekklesiologie ten opsigte van die spanning eenheid-verskeidenheid en inklusiwiteiteksklusiwiteit. Die relatiewe waarde van die klassieke notae ecclesiae en die resente insig in agape en koinōnia as die relevante notae vir hedendaagse kerk-wees (Berkhof 1962a:85, 1962b:153; Snyder 2002:22; vgl. Van Wyk 2013b:94) is só gesien, ook die positiewe gevolge van 'n evangeliese antwoord op die katastrofes van die twintigste eeu.

Die 'ellipsis' in die sekwensie van die Europese narratief en dié in Suid-Afrika het 'n onvermoë om die dominante ideologieë, gebore in die negentiende en twintigste eeu te demistifiseer, meegebring. Die Afrikaanssprekende kerk $^{1}$ het as gevolg van isolasie, veroorsaak deur die apartheidsideologie, nie werklike ekumenisiteit geïnternaliseer nie. Dit is so asof die verandering in konteks ná die negentiende en twintigste eeu waarbinne religie in Europa beoefen is, nie 'n volledige paradigmaskuif in Suid-Afrika meegebring het nie. Meer nog, dit is asof die volkskerklike milieu van die negentiendeeeuse Nederland in die Afrikaanssprekende kerk gestol het.

Vervolgens sal daar eerstens aandag gegee word aan die rol wat die begrippe 'nasie' en 'volk' in die religie van negentiende-eeuse Europa gespeel het en tweedens, die begrippe 'nasie' en 'volk' in die kerk in die negentiende eeu in Nederland gespeel het, en derdens hoe die kombinasie van 'nasie', 'volk' en 'kerk' die konteks waarbinne die Afrikaanssprekende kerk apartheid teologies geregverdig het, gevorm het. Die ideologie van apartheid in die kerk staan dus in noue verband met negentiende-eeuse religie in Europa en die negentiende-eeuse kerk in Nederland.

\section{'Nasie', 'volk' en religie in Frankryk, Engeland en Duitsland}

Die Franse Revolusie moet gesien word as die beginpunt van politieke 'nasionalisme' in Europa (Moxnes 2012:1). Hierdie vroeë 'nasionalisme' het betrekking op die modernisering van bepaalde vorms van gesag en politiek en het van die begin af anti-monargale sentimente gehad. Die doel van hierdie modernisering was om mag vanaf die monarg en die burokrasie na die 'gewone mense' in 'n bepaalde gebied te verplaas. Hierdie politieke hervormings was gegrond op die filosofie van enersyds anti-aristokrasie en/of anti-hiërargiese (opstand teen die hegemonie van die staat in alliansie met die kerk) en andersyds die belang van demokrasie, die regte van die bourgeoisie ('n handelsmiddelklas) en die reg van 'volke' en

1.Waar daar in hierdie artikel 'Afrikaanssprekende kerk' gebruik word, verwys dit na die Nederduitsch Hervormde Kerk van Afrika, die Nederduitse Gereformeerde Kerk, die Gereformeerde Kerke in Suid Afrika. hulle 'unieke' kultuur, met die implikasie van vryheid ten opsigte van handeldryf en godsdiens (kyk Brown \& Tackett 2006:536-556).

Tot en met die negentiende eeu was daar nie 'n klinkklare 'definisie' van wat 'n nasie sou wees nie (Moxnes 2012:9). Die begrippe 'nasionalisme' en 'nasie-staat' was daarom ook nie tot en met daardie tydperk vanselfsprekend of selfs 'natuurlik' nie (Özkirimli 2005:12-57). Die begrip 'staat' het weliswaar 'n geruime tyd reeds voorgekom, maar is nie sonder meer met die begrip 'nasie-wees' verbind nie (Moxnes 2012:9). Die ontstaan van die begrip 'nasionalisme' hou verband met die negentiende-eeuse sosiale en politieke bewegings en dié se praktyke om 'nasie-state' te skep of te hervorm. Tog is Kedourie (1960:187) se siening te eng, naamlik: ' $[N]$ ationalism is a doctrine invented in Europe at the beginning of the nineteenth century' (vgl. Moxnes 2012:9). 'Nasionalisme' is nie 'n ideologie wat oornag uitgedink is nie. Dit was 'n beweging wat in 'n spesifieke tyd ontstaan en ontwikkel het, omdat spesifieke situasies en politieke en sosiale probleme nuwe vrae en oplossings opgeroep het (kyk veral Ernest Renan ${ }^{2}$ se 1882-Sorbonne lesing 'Wat is 'n nasie?'). Ook Breuilly (2002) meen dat die begrip 'nasionalisme':

in times with a heavy rate of modernization that demanded new solutions where appeals to tradition no longer carried conviction and one had to construct images of the future which were not forward projections of one's understanding of the past (bl. 246)

ontstaan het. Hy beklemtoon egter dat die verdere ontwikkeling van die begrip 'nasionalisme' verband hou met die kulturele betekenis wat aan 'nasie' toegeken is. Beide die begrippe 'nasie' en 'nasionalisme' het identiteitsmerkers geword om uitdrukking te gee aan sosiale rolle, waardes en sosiale geslagsrolle. Anderson (1983:36-50) meen dat die kulturele betekenis van die begrip nasionalisme 'constructed' of 'imagined' van aard is, en daarom word die inhoud daarvan telkens deur kontemporêre konteks en relativerende omstandighede bepaal.

In die negentiende eeu het die belangrikste sosio-religieuse kwessies in Europa 'n soort 'influksiepunt' begin vorm - en met hierdie term word bedoel dat gebeure, soos wanneer verskillende riviere op 'n punt saamvloei, 'n maalkolk veroorsaak en die vloei van die rivier versteur. In hierdie turbulente tyd het die begrippe 'nasie' en 'nasionalisme' (wat met mekaar ineengevleg was) 'n groot rol in politieke en religieuse idees begin speel. Kerklik het die hiërargie (regering deur geestelikes) met die regeermag van die aristokrasie 'n alliansie gevorm (vgl. Lenski, Nolan \& Lenski ([1970] 1995:209). Polities gesien is hierdie tydperk gekenmerk deur die daarstelling en ontwikkeling van 'nasie-state' wat gekombineer is met en ondersteun is deur die uitbreiding van kolonialisme en imperialisme. Hierdie tydperk is sterk beïnvloed deur die dramatiese veranderinge op die gebiede van handel en arbeid asook sosiale onderskeidings met betrekking tot groepe, families en geslagsrolle. Die

2.Ernest Renan (1996) is een van die pionierdenkers wat die diskoers oor 'nasie' en 'nasieskap' geskep en rigtinggewend beïnvloed het. In sy 1882-Sorbonne lesing sê hy dat die sentiment van 'nasionaliteite' nie eers'n honderd jaar oud is nie. Volgens hy dat die sentiment van 'nasionaliteite' nie eers ' $n$ honderd jaar oud is nie. Volgens Franse Revolusie teruggevoer word (kyk Abizadeh 2004:291-313). 
stabiliteit wat hierdie verhoudings voorheen in tradisionele gemeenskappe gekenmerk het, is beëindig. Die karakter en identiteit van ontluikende 'nasie-state' is ingrypend beïnvloed deur die nuwe diskoers oor die vryheid en rol van burgers asook die diskoers oor die verhoudings tussen sosiale klasse onderling en oor die struktuur van familie, geslagtelikheid en publieke moraliteit (kyk Brown \& Tackett 2006:536-556).

Hierdie verandering in denkklimaat het dit onmoontlik gemaak 'to appeal to religious or dynastic or customary justification for authority' (Breuilly 2002:209). Politieke verandering het die weg vir nuwe denke en idees gebaan. Duitsland is 'n voorbeeld van hoe die kulturele elite (te onderskei van die politieke elite) 'n beduidende rol en plek in die diskoers oor 'nasionalisme' gekry het, veral in die beginfase daarvan. In Duitsland het 'nasionale' simboliek en beeldspraak in ' $n$ betreklike kort tydperk (die begin van die negentiende tot en met die middel en laat negentiende eeu) tot stand gekom wat deur die meerderheid aanvaar en in die middelpunt van die politieke diskoers geplaas is. Hierdie diskoers was die begin van die begronding van 'n 'nasie-staat'.

Bestaande en potensiële politieke maghebbers het die idee van 'nasionalisme' begin gebruik om gesag te legitimeer en om die 'nasie-staat' teen interne en eksterne bedreigings te beskerm (Moxnes 2012:10). Die begin van die 'identifikasie' van 'nasionalisme' en die latere koppeling daarvan met 'nasie-staat', en nog later die uitwasse daarvan in die ideologie van die 'nasionaal-sosialisme' - spesifiek met Duitsland as voorbeeld - word deur die Noorweegse teoloog Halvor Moxnes (2012) na die invloed van Friedrich Schleiermacher (1768-1834) teruggevoer.

Gedurende 1819-1832 het Schleiermacher in Berlyn sy beroemde lesings oor die lewe van Jesus ${ }^{3}$ (vgl. Schleiermacher 1864) gelewer. Volgens Moxnes (2012:8) het hierdie lesings ' $\mathrm{n}$ beweging verteenwoordig waarin die 'dogmatic presentations of Christ' verander is in ' $\mathrm{n}$ 'biography of the historical human Jesus':

[it] was a seismic shift in religious and political symbolism; from Christ as a celestial symbol of the church and the monarch to Jesus as a critical symbol of individuals and a people. (Moxnes 2012:8)

Op daardie stadium was die Pruisiese Duitsers polities aan die Franse monargie ondergeskik as gevolg van die Napoleontiese verowering van Pruisiese grondgebied. Dit het tot ' $n$ einde gekom met die slag van Waterloo in 1815. Aanvanklik het Pruise ' $n$ beduidende rol in die vryheidstryd van die Franse 'kleinboere' en bourgeoisie-handelsklas teen die Lodewyk-aristokrasie gespeel. Sedert 1790 het die Fête de la Fédération in Frankryk 'n nasionale kultuurgebeurtenis geword om die bestorming van die Bastille op 14 Julie 1789

3.Ook David Friedrich Strauß beïnvloed die diskoers oor Duitse nasionalisme met sy twe boeke: Das Leben Jesu, kritisch bearbeitet (1835) en Das Leben Jesu für das (weutsche Volk, (1864). Die tweede boek reflekt (1835) en Das Leben Jesu fur das cu sche Volk, (1864). Die tweede boek reflekteer op die invoed van "nasionalisme" op die staat in die tydperk tot en met die regering van Otto von Bismarck. In sy Der Christus des Glaubens und der Jesus der Geschichte (1865) lewer Strauß ster kritiek op die Jesus-studie van Friedrich Schleiermacher. as aanvang van die Franse Revolusie te vier (vgl. Nord 1995:205). Die jong Franse demokrasie het egter vinnig plek gemaak vir die nuwe Napoleontiese outokrasie. Die historikus Philip Nord (1995) beskryf hierdie verwikkeling soos volg:

Since the first Napoleon, France's minority religions - Protestant and Jewish - had been organized to consistories, bodies invested with a double mandate: to present vis-à-vis the state the interests of the faithful and to perform vis-à-vis the faithful a variety of policing functions. Consistorial boards were mainly composed of lay representatives elected, in the Jewish case, by universal suffrage, in the Protestant by a more restricted franchise. Louis-Napoleon subjected both consistories to a constitutional overhaul. The political motive was to strengthen those religious currents well disposed to the regime or at least to weaken potential opponents ... From the empire's point of view, the Reformed Church's governing elite represented a problem of a different sort ... Louis-Napoleon accordingly curried favor with liberal, antiorthodox currents in the Reformed Church ... Louis-Napoleon left the scene in 1870 but he was succeeded by the centrist administration ... which was authoritarian and clerical-minded in its policies. In the circumstances middle-class discontent did not flag but even intensified. (bl. 12-13)

Die verowering van Frankryk deur die Pruisiese keiser in 1870-1871 was nie net die begin van die ontwaking van Duitse nasionalisme nie (kyk Howard 2001:518), maar het ook die totale politieke en kerklike toneel in Europa (en in Suid-Afrika) verander. Die eeue-ou verleiding om genealogie as 'n beslissende konstitutiewe element van kerk-wees te reken, het die gevolg dat kerk as instituut vir sommige 'staatskerk' geword het, vir ander 'nasionale kerk' en weer vir ander 'volkskerk'.

Die aanloop tot die opkoms van die begrip 'nasie-kerk', het in ' $n$ sekere sin begin toe Napoleon Bonaparte Pruise in 1806 ingeval het (kyk o.a. Barnes 2010:27). Friedrich Schleiermacher het in 1804 vanaf Berlyn na Halle gegaan om 'n professoraat in Halle (waar hy as student gestudeer het) te aanvaar (Reed 2004:2 van 33). Toe Napoleon met sy inval die universiteit tot niet gemaak het, het Schleiermacher na Berlyn teruggekeer (Reed 2004:2 van 33). ${ }^{4}$ In sy Jesus-lesings in Berlyn beklemtoon Schleiermacher die begrip 'vryheid' en met sterk 'nasionale' sentiment beywer hy hom vir die vryheid van sy eie 'vaderland' - vryheid wat deur die nasionale 'koning en nasie' verwesenlik moet word en nie deur 'konings en hulle weermag met huurtroepe' nie (kyk Schleiermacher 1890:67-83). Hiermee wou Schleiermacher die Duitsers oproep om hulleself van die hegemonie van Frankryk te bevry.

Dit is teen hierdie agtergrond dat die begrip 'nasie' na die Duitse 'volk' begin verwys het. 'Nasie' het 'n kollektiewe betekenis gekry wat na sowel 'burger as regeerder' verwys. So het die begrip 'nasie' en die begrip 'volk' onlosmaaklik met mekaar begin verband hou, en 'staat' en 'kerk' is aan mekaar gebind. In Duitsland het die 'volkskerk'-idee egter 4. Vir' $n$ volledige oorsig van die teologie- en filosofiegeskiedenis van Pruise in hierdie tydperk, kyk onder andere Dilthey (1936), Bigler (1972) en Howard (2001). 
swaar belas begin raak omdat dit as 'nasie-kerk' verstaan is en deur nasionaal-sosialisme as gevolg van Adolf Hitler se Nazi-regime gekontamineer is. Teoloë soos Karl Barth, Rudolf Bultmann en Dietrich Bonhoeffer het skerp reageer op hierdie aantasting van die outentisiteit van kerk-wees (kyk Jeanrond 1992:187-203). Met die stigting van die 'Bekennende Kirche' [die Belydende Kerk] is die kerk 'los' van die staat én die nasie gemaak. ${ }^{5}$

In teenstelling met die situasie in Duitsland, was Engeland en Frankryk reeds voor die opkoms van nasionaal-sosialisme 'nasie-state' in die sin dat die begrip 'staat' die begrip 'nasie' voorafgegaan het (Moxnes 2012:10). In Engeland was die gemeenskaplike 'nasionale' identiteit met die opkoms van Anglo-Saksonisme reeds gevestig (Lowenthal 1991:205-230; kyk Towell 2003). In Frankryk was die Franse Revolusie die oorsaak dat 'nasie' na die nie-regerende inwoners van die land begin verwys het (Moxnes 2012:10). Franse 'nasionalisme' was gegrond op 'n gemeenskaplike geskiedenis en 'n verbintenis tot ' $\mathrm{n}$ gedeelde toekoms. In hierdie opsig het die teoloog Ernest Renan se lesing 'Qu'est-ce qu'une nation?' ['Wat is 'n nasie?'] 'n belangrike bydrae in 1882 tot die ontwikkeling van die betekenis van die begrip 'nasionalisme' in Frankryk gemaak (Moxnes 2012:2-3).

In Engeland was 'nasionale identiteit' geassosieer met 'nasionale karakter' - soos dit gesien kan word in George Adam Smith ([1894] 1910) se publikasies waarin hy 'nasionalisme' beskryf in terme van moraal en in terme van wat hy 'n 'manly' karakter genoem het. Duitse 'nasionalisme' het in teenstelling met beide die Franse en Engelse gebruik, ras en afkoms as kenmerke van 'nasionale' identiteit beskou (vgl. Peukert 1987:220). Hierdie verskynsel kan 'etno-nasionalisme' genoem word.

Moxnes (2012:11) beskryf 'ethno-nationalism' as die heersende dominante ideologie van die staat. Etno-nasionalisme is gegrond op die gedagte dat 'n volk deur etnisiteit bepaal word en dat ' $n$ 'koherente' etniese groep ' $n$ 'nasie' vorm. In die raamwerk van hierdie ideologie is dit ook vanselfsprekend aanvaar dat elke nasie 'n eie staat en grondgebied moet hê. Volgens Moxnes lê daar dus agter die begrip 'volk' 'n ideologiese konstruksie. Om hierdie rede is die verhouding tussen 'nasie' en 'volk' in die Europese kerk- en politieke geskiedenis 'n komplekse aangeleentheid.

In die agtiende eeu het verskillende begrippe in verskillende tale as uitdrukking gedien vir wat hedendaags 'volk' genoem word, byvoorbeeld people, 'gepeupel' en populus. Hierdie begrippe was in ' $n$ pejoratiewe sin gebruik om te verwys na 'n groot massa mense, dit wil sê 'common people' (Leersen 2006:209). Twee gevalle (invloede) kan dien as voorbeelde hoe hierdie 'betekenis' in onderskeidelik Frankryk en Duitsland verander het en dat dit konstant daarna 'n invloed op die gebruik van die begrip 'nasie' in politiek en die kerklike lewe uitgeoefen het. Die een is die rol

5.'n Soortgelyke geskiedenis het in die tagtigerjare in Suid-Afrika afgespeel met die opstel van die Belhar-belydenis as appèl op die vergrype van die apartheidsregering van die Nasionale Party in die jare 1948-1992 (kyk o.a. Nico Koopman 2008). wat Emmanuel Joseph Sieyès (1748-1836) gespeel het en die ander die rol van Joseph Ernest Renan (1823-1892).

In die gebeure wat gelei het tot die Franse Revolusie in 1789 het die jong priester Emmanuel Sieyès (kyk Leersen 2006:86) in 'n pamflet (in Engels vertaal as 'The third estate: What is that?') met die begrip 'Derde Stand' die nie-adellike deel van die bevolking, die Franse gemeenskap, bedoel. Hier lê die eerste oorsprong van die gebruik 'nasie'. Volgens Sieyès het die 'Eerste Stand' na klerikales verwys en die 'Tweede Stand' na die adellikes. Hierdie 'koninklikes' het hy nie as outentieke deel van die Franse bevolking gereken nie, omdat hulle op die nie-adellike deel (die eintlike volk) geparasiteer het. Hierdie onderskeid deur die jong priester het só 'n invloed op die lewe in Frankryk uitgeoefen dat Lodewyk XVI die 'drie stande' op 14 September 1791 bymekaar geroep het om Frankryk se ekonomiese krisis te bespreek. Toe die byeenkoms verdaag word, het die 'Derde Stand' geweier om te vertrek. Hulle verwys na hulleself as die Assemblée nationale. Sodoende is die woord 'nasie' gebore en wel as verwysend na die 'Derde Stand' se stryd teen die koning. Op hierdie manier het die term 'nasie' die betekenis begin kry om te verwys na die burgers ('patriotte') wat saam 'n volk konstitueer, in teenstelling met hulle vorige status as onderdane van 'n koning (Moxnes 2012:10-12).

Die gedagte van ' $n$ nasie as bestaande uit 'vrye burgers' (patriotte versus royaliste) is verder ontwikkel in Ernest Renan se lesing (waarna bo verwys is) in 1882 getitel, 'Qu'est-ce qu'une nation? ['Wat is 'n nasie?'] (Renan 1996). Renan het die ideale van die Franse denke oor 'nasie' (wat met gedeelde politieke geskiedenis en lojaliteit aan die grondwet verband hou) verteenwoordig. Hy het sy argumente sterk in teenstelling met die Duitse denke oor 'nasie' verwoord. Vir die Duitsers was die begrip 'nasie' gegrond op 'n gemeenskaplike taal en ook op ras (Renan 1996).

In dieselfde tydperk as waarin Sieyès sy argument gevoer het, het Johann Gottfried Herder (1744-1803) (kyk Spencer 2012:129-157) in Duitsland die pejoratiewe semantiese betekenis 'volk' as populus ('common people') gewysig tot 'n begrip verwysende na 'n gemeenskap van mense wat gekonstitueer word deur 'n gemeenskaplike taal en kultuur en waarvan die wortels teruggaan na volksoorleweringe, tradisies en gebruike van die 'laer klasse' (vgl. Leersen 2006:97-101). Moxnes (2012:12) verwoord dit soos volg: '[T] his made up the national identity that was unique for each nation and defined through its difference from other nations.'

Die filosoof Jürgen Habermas (2001:1-25) het die diskoers hoe Duitse akademici die vraag, 'Wat is 'n volk?' in die geesteswetenskappe in 1846 bespreek het, ontleed. Hy wys daarop dat hulle die universaliserende beginsels van 'populêre heerskappy' (die erfenis van die Franse Revolusie) as interessant beskryf, maar dat hulle nie bereid was om hierdie universaliserende beginsels in 'n politieke omgewing te akkommodeer wat deur die 'nasie' (verbind aan ' $n$ spesifieke grondgebied, genealogiese herkoms, taal en 
kultuur) gedefinieer is nie (vgl. Habermas 2001:xv). Tog het 'bloed en bodem' (ras en land) inherente komponente van die begrip 'nasie' geword (vgl. Schama 1977:581-600, 1995):

The national territory (i.e. territory of the nation) became the 'natural' as well as institutionalized space within which the constitutional project could be realized. In addition, since territory was an important part of the definition of nation, borders and boundaries served to create distinctions, to distinguish both geographically and socially between 'us' and 'others'. (Breuilly 2002:213-214)

\section{'Nasie', 'volk', en Kerk in Nederland}

Bogenoemde ontwikkeling en ontstaan van die begrip 'nasie' in Engeland, Frankryk en Duitsland vertoon 'n parallelle geskiedenis in Nederland, hoewel met unieke karaktertrekke. In die Verenigde Nederlande het Prins Willem I (1533-1548) van Oranje-Nassau 'n soortgelyke rol as Otto von Bismarck in Pruisiese Duitsland vervul. Hy het konstant protes aangeteken teen vreemde oorheersers in Nederland. Dit het gelei tot die konstitusionele monargie wat in 1815 onder Willem Frederik VI begin is. Hy het na homself as Willem I begin verwys, hoewel die geskiedenis van die Oranje-dinastie met Willem de Zwijger begin het.

Willem I is gebore op 24 April in 1533 en is op 10 Julie 1584 in Delft vermoor op grond van instigasie deur die Spaanse koningshuis. Willem I se protes teen die oorheersing van die Rooms-Katolieke Spaanse koningshuis het gelei tot die tagtigjarige oorlog wat op 21 Julie 1568 begin het. Hy is as Lutheraan gebore en het as Rooms-Katoliek grootgeword. Hy het deurgaans simpatie met die vervolgde Franse Hugenote en Nederlandse Calviniste gehad en het self in 1573 'n Calvinis geword.

Die beëindiging van die Spaanse tagtigjarige oorlog in 1648 het gelei tot die Verenigde Nederlandse Provinsies en dit het in die negentiende eeu 'n konstitusionele monargie geword. België het in 1830 onafhanklikheid verklaar, maar die onafhanklikheid is eers deur die Nederlandse Huis van Oranje-Nassau in 1839 ná 'n bloedige oorlog erken. Die dogter van Willem III, Wilhelmina, het die koningin van Nederland geword in 1890, was simbool van die Nederlandse weerstand teen Duitse nasionaal-sosialisme, en het na die Tweede Wêreldoorlog, ná 'n periode van agt en vyftig jaar, in 1948 geabdikeer ten gunste van haar dogter, prinses Juliana.

Sedert 1815, toe Willem Frederik VI die eerste koning van die Verenigde Nederlande geword het, heg die konstitusie geen religieus-denominasionele koppeling aan die Huis van Oranje-Nassau nie, hoewel die dinastie formeel lidmate was van die destydse Nederlandse Hervormde Kerk (nou saam met die Gereformeerde Kerke Nederland en die Lutherse Kerk verenig as die Protestantse Kerk in Nederland). Min of meer $26 \%$ Nederlanders is tans lidmate van die RoomsKatolieke Kerk, 17\% Protestants, 6\% Moslem, 10\% ander gelowe en $41 \%$ wat aan geen denominasie verbind is nie. Koning Willem Frederik VI is byvoorbeeld in 1772 in De Grote Kerk in Den Haag (wat in 1574 na die Reformasie die eiendom van die Nederlandse Hervormde Kerk geword het) gedoop.

Die Nederlandse Hervormde Kerk was in Nederland die 'bevoorrechte kerk' (kyk Santing-Wubs 2002:1-14). Hierdie denominasie was egter nooit formeel 'staatskerk' genoem nie, daar die 'bevoorregting' in werklikheid op 'n informele 'staatskerk' neergekom het. ${ }^{6}$ Die Hervormde Kerk is byvoorbeeld met staatsgeld gefinansier, omdat die instandhouding van die Hervormde Kerk 'door de overheid gezien [is] als openbaar belang' en die 'christelijke hervormde Godsdienst is die van den Souvereinen Vorst' (Santing-Wubs 2002:11). Die koning het volgens Artikel 139 van die konstitusie die reg gehad om beheer oor die kerk uit te oefen.

Die uitwerking van die Franse en Noord-Amerikaanse revolusies het in 1795 in Nederland tot die 'Bataafse omwenteling' gelei. Kerk en staat is konstitusioneel geskei (kyk Ten Hooven \& De Wit 2006), die Republiek der Verenigde Nederlanden is vervang met 'n eenheidstaat onder leiding van Frankryk (Oldenhuis et al. 2007:9). Die konflik in die Hervormde Kerk en die afskeiding van konfessionalistiese 'dolerendes' - 'n proses wat in 1834 begin het - het uiteindelik daartoe gelei dat koning Willem I (Willem Frederik VI) vanaf 1840 sy rigiede teenstand teen 'afskeidendes' laat vaar het (kyk Elzinga, De Lange \& Hoogers 2006:366-367, 373).

Reeds in 1796 het die Nationale Vergadering van de Bataafse Republiek die skeiding tussen kerk en staat gelegitimeer. Die sinode van die Nederlandse Hervormde Kerk het in 1851 die Algemeen Reglement aanvaar waarin die kerk 'een volledige vrijheid van beweging ten opzichte van de overheid kreeg' (Elzinga et al. 2006:373). Dit het veronderstel dat alle denominasies gelyke behandeling moes ontvang en dat alle burgers op godsdiensvryheid geregtig was. Dit het egter nie die einde van religie beteken nie, want:

[t]en tijde van de Bataafse Republiek wordt de rol van religie van groot belang geacht voor de maatschappij en de politiek; de nadruk wordt gelegd op de gemeenschappelijke christelijke identiteit. (Oldenhuis et al. 2007:10)

Op hierdie wyse het ' $n$ informele 'staatskerk' in werklikheid 'n 'nasie-kerk' gevorm en die 'kerstening van die kultuur' is gegrond op die feit dat die vroeëre 'bevoorregte' Hervormde Kerk onder die voorwendsel van om 'volkskerk' te wees, dié kerk se stempel op die 'nasie' wou afdruk. Oldenhuis et al. (2007) beskryf die konflikterende konsekwensie soos volg:

Deze zienswijze stuit op verzet vanuit verschillende kerkgenootschappen in Nederland. De orthodoxe protestanten en later ook de katholieken pleiten voor bijzondere scholen waarin specifiek godsdienstonderwijs wordt gegeven. De schoolstrijd die hieruit is ontstaan heeft aanvankelijk primair een godsdienstige en kerkelijke achtergrond. Wanneer de roep om bijzonder onderwijs geen gehoor vindt bij de gevestigde politiek, krijgt zij tevens een politiek karakter. Er ontstaat een

6.In die Zuid-Afrikaanse Republiek het 'bevoorregting' formeel neerslag gevind (kyk verder in hierdie hoofstuk). Konstitusioneel is bepaal dat om in aanmerking (kyk verder in hierdie hoofstuk). Konstitusioneel is bepaal dat om in aanmerking te kom om as staatspresident verkies te word, iemand lid van die 'staatskerk' moes wees, te wete die Nederduitsch Hervormde Kerk (vgl. Argief-Jaarboek vi Suid-Afrikaanse Geskiedenis 1955:135) 
grote politieke beweging die uitmondt in partijvorming op confessionele grondslag. (bl. 10)

Wat op grond van hierdie oorsig van die Nederlandse kerklike toneel duidelik is, is dat 'nasionaliteit' aanvanklik 'staatskerk' veronderstel het en dat die begrippe 'nasie' en 'volk' op dieselfde saak gedui het. Vir die Huis van OranjeNassau was die 'staat' tot en met 1840 tegelyk die 'kerk' en die 'nasie'. In hierdie opsig het koning Willem in sekere sin dieselfde as Schleiermacher (1890:67-83) in gedagte gehad met sy uitdrukking 'koning en nasie' téénoor 'konings en hulle weermag met huurtroepe', verwysende na die oproep dat die 'nasie' - dit wil sê die 'kerk' - sigself van die hegemonie van Frankryk moet bevry.

Na die Franse Revolusie het daar in Frankryk spoedig nie net ' $n$ algehele breuk tussen die 'informele staatskerk' (in hierdie geval die Rooms-Katolieke Kerk) en 'nasie-kerk' en/of 'volkskerk' (die spiritualiteit van die bourgeoisie) ontstaan nie, maar Frankryk het volledig gesekulariseer. Dit het nie teen dieselfde vinnige tempo in Nederland plaasgevind nie. Die Huis van Oranje-Nassau was die 'staat' en het die 'bevoorregte' Hervormde Kerk op informele wyse as 'staatskerk' in stand gehou. Koning Willem het die 'volk' verteenwoordig ('king and nation') ten spyte daarvan dat die konstitusie 'n skeiding tussen 'staatskerk' en 'nasiekerk'en/of 'volkskerk' gereglementeer het. Die sinode van die Nederlandse Hervormde Kerk stel 'n 'kerkwet' (Algemeen Reglement) op. Hiermee word die 'kerkwet' uit die konstitusie uitgehaal - en wat oorbly, is 'n 'volkskerk' wat beheer oor die 'nasie' wil bly uitoefen totdat die antimonargale pro-Bataafse gesinde 'republikeine' met ' $n$ 'dolerende' afskeidingsbeweging nie net 'n 'Christelike politieke party' stig nie, maar ook 'n aparte kerk wat 'vry' kan wees ten opsigte van die 'volkskerk' wat beheer oor die 'nasie' wil bly uitoefen.

'Afskeidendes' in Nederland het ook nasionaal-sosialistiese tendense soos anti-Semitiese rassisme vertoon (kyk Jonker 1989:19). Wat die vroeëre bevoorregte 'volkskerk' en/of 'nasie-kerk' betref, het die toenemende sekularisasie in Nederland meegebring dat die sogenaamde 'volkskerklike' missionaat wat die 'nasionale' kultuur wou kersten, al hoe meer funksionaliteit verloor het.?

Die Nederlandse situasie en ervaring is analogies ten opsigte van die Suid-Afrikaanse kerklike toneel. Daar is egter een belangrike verskil tussen Nederland en Suid-Afrika. Die Nederlandse volkskerk het nie ras aan nasionale identiteit gekoppel nie, behalwe die konfessionele ortodokses wat dit wel gedoen het. Laasgenoemde kom ooreen met dít wat in Duitsland onder die nasionaal-sosialisme gebeur het.

Waar die 'nasie'-gesinde Nederlanders met die term 'volkskerk' die 'kerstening van kultuur' in gedagte gehad het, het die hart van die 'kultuur' in Suid-Afrika op 'afsonderlike

7.Onder andere het Hoekendijk (1948) die volkskerkgedagte as ' $n$ uitgediende begrip beskryf (vgl. ook Dürr 1947). Kees de Groot (2005:15-16) toon aan dat die idee onaanvaarbaar in Europa geword het as gevolg van die dialektiese teologie se invloed. Dit het meegebring dat die kerk as 'n 'diensverleningsorganisasie' gesien moet word en nie 'n organisasie wat mense doelbewus in een kultuur sosialiseer moet word en nie ' $n$ organisasie wat mense doelbewus in een
nie. Laasgenoemde is volgens hom nie die taak van die kerk nie. ontwikkeling' ten opsigte van rasse gedui. So is apartheid nie net met 'nasionale' sentiment geregverdig nie, maar ook missionaal op grond van teologiese oorwegings. Die begrip 'volkskerk' in terme van 'king and nation' het dus nie in Nederland dieselfde betekenis gehad as wat dit in SuidAfrika gekry het nie. Tosh, Hagemann en Dudink (2004) stel dit soos volg:

Since nationality is a relational term based on systems of difference and hierarchies, other identities that likewise are associated with differences and hierarchies are used to express ideas about nation, especially family, sexuality, gender and race. (bl. 48)

Waar die begrip 'volkskerk' in 'n baie spesifieke situasie in Nederland tot stand gekom het, te wete 'n konteks wat wesenlik anti-hegemonies (teen Franse oorheersing) was, het die begrip in Suid-Afrika in die Afrikaanssprekende kerk 'n instrument geword om juis hegemonie teen wat rasmatig anders is, in stand te hou. Wat in kerk-wees in post-apartheid Suid-Afrika vandag nodig geword het, is die voltrekking van die transendering van 'nasie-kerk'. Post-apartheid Suid-Afrika gaan mank aan sosiale kohesie en daarom is die kerk voor die groot uitdaging om eenheid in verskeidenheid te laat realiseer.

\section{Kerk-wees as ellips van versoenende verskeidenheid - 'n Oop toekoms vir die Kerk}

Paulus se beskrywing van die ekklēsia is dié van 'n ruimte waar ' $n$ verskeidenheid van relasies voorkom en waar eenheid nie eers in die toekoms realiseer nie, maar wel in die hede, hier en nou. In hierdie ruimte word gevind dat God 'alles vir almal gee' - veral vir die ongewenstes (1 Kor 12:6); dat God 'alles vir almal is' - omdat God verganklikheid oorstyg (1 Kor 15:28). En só word 'die Ek alles vir almal', sodat 'almal' (die Ander) deur God van verganklikheid gered kan word - 'die Ek' doen dit 'alles ter wille van die evangelie', sodat die Ek saam met die Ander aan die evangelie deel het (sugkoinōnos) (1 Kor 9:23, 25).

Vervolgens word daaraan aandag gegee om die epistemologiese struikelblokke in die ekklesiologiese besinning oor die verhouding 'eenheid-diversiteit' te oorkom.

Radikale inklusiwiteit is dié uitdaging waarvoor die ekklēsia in die konteks van die hedendaagse postsekulariteit te staan gekom het. Postsekulariteit behoort nie die 'end of religion' te impliseer nie, maar 'rather the end of exclusive humanism' (Van Aarde 2009:7 van 8). ${ }^{8}$ Postmoderniteit bied aan die postsekulêre kerk die geleentheid om die uitdaging van

8. Let op dat die begrip 'postsekulariteit' gespel word sonder ' $n$ koppelteken, met ander woord nie as 'post-sekulariteit' nie. Vir die belangrike verskil in betekenis, kyk Van Aarde (2009:2 van 8): 'However, the critical part of the definition ... has to do with the prefix "post-", which signifies two different meanings in one compound word. The same applies to a discussion within the field of postcolonia compound word. The same applies to a discussion within the field of postcolonial theory (Ashcroft, Griffiths \& Tiffin 1995:1-4; Moore 2000:182-188) and that of "postmodernity" (e.g. Schrag 1997:69-74, 129; Van Huyssteen 1999:137-139) According to Moore (2000:182), a conception of 'post (-) can be viewed as 'naïve, inadequate, or utopian'. Young (1996:67-68) points out that the prefix "post-" is symptomatic of putting "oneself on the outside" by assuming a "postness" and a "newness", to such an extent that one gets outside oneself by stepping outside one's "own skin"' (oorspronklike bronverwysings verminder). 
radikale inklusiwiteit en 'n epistemologie, ontologie (met 'n daaruitspruitende etiek) te aanvaar wat beskryf kan word as versoenende verskeidenheid. Die uitdaging is om die konstruktiewe elemente van postmoderniteit vir kerk-wees op positiewe wyse te verinnerlik. Die 'publieke praktiese teoloog' van Chester (Engeland), Elaine Graham (2002) verwoord dit soos volg:

qualities of the postmodern condition that might be of value: its fluidity, its pluralism and questioning of authority, its resistance to exclusivism and its openness to religious sensibilities characteristic of the postmodern return of the sacred. (bl. 138)

Wat Allan Boesak en Curtiss Paul DeYoung (2012) oor 'radikale versoening' sê, geld ook vir die begrip 'inklusiwiteit', ofte wel 'eenheid'. 'n Handves van menseregte en 'n grondwet kan in die politieke sfeer beskermende maatreëls deur wetgewing proklameer, maar vanuit 'n teologiese perspektief ernstige tekortkominge hê. Die tekortkoming is naamlik dat versoening nie radikaal geleef word nie en niks anders is nie as 'political pietism'. As versoening die ideaal van kerklike belydenisse en sinodale besluite is, maar dit word nie 'n werklikheid in die etiese houding en gedrag van mense nie, is dit 'Christian quietism' - 'n 'wag-maar-tot-eendag' houding. Daarom is die hoof- en subtitel van Boesak en DeYoung (2012) se boek ook vir die ekklesiologie relevant: Radical reconciliation: Beyond political pietism and Christian quietism.

In die 'eenheid van die kerk'-hoofstuk in 1 Korintiërs 12, beklemtoon Paulus die energie van die één Pneuma, Kurios en God. Dit lyk asof Paulus tegelyk inklusief én hiërargies dink. Wat hy egter beoog, is dat daar aan die onaanvaarbare lid van die liggaam groter beskerming en selfs groter eer verleen moet word (1 Kor 12:22-25). Dan kan bely word dat 'God alles vir almal' (1 Kor 12:6) is. Dan kan op grond van die Gees van God bely word dat 'Christus Jesus die Kurios' is (1 Kor 12:3), ontdaan van skynvroomheid en skynentoesiasme.

Karl Barth ([1935] 1964:12) se interpretasie van die belydenis van die eenheid van die kerk is dat die 'algemeenheid' (catholica) die kerk se 'heiligheid' (sancta) is:

Alleen daar waar die kerk in essensie en in beslissende bereidwilligheid, catholica [algemeen] is, is dit sancta [heilig] is dit ecclesia [kerk] ... Die verbintenis met 'n volk, 'n staat of 'n kultuur mag nooit veroorsaak dat die kerk hierdie catholica (algemeenheid) verloën nie. (bl. 12)

Die opmerking van Barth is 'n belangrike heuristiese riglyn. Vanuit hierdie perspektief kan begryp word waarom Paulus se diskoers oor die kerk (1 Kor 12) ineenvloei met sy diskoers oor die liefde en Christō (1 Kor 13): '[K]om ek vertel jou wat die nog meer uitnemende is.' De Reuver (2004) beskryf hierdie ekklesiologiese insigte op grond van Paulus se liggaamsbeeld in 1 Korintiërs soos volg:

De overvloedige rijkdom van de drie-enige God kan slechts adequaat bezongen worden door een veelstemmig koor ... De eenheid in Christus wordt ook manifest in de christelijke gemeente als gemeenschap. De christelijke gemeente is geen optelsom van individuele gelovigen, maarhet ene lichaam van
Christus. Christus bepaalt de identiteit van de afzonderlijke leden en maakthen één. Volgelingen van Jezus zijn geen eenlingen, maar leden van één lichaam. Zij behoren Christus toe en daarom zijn zij bij elkaar. Geloven los van het ene lichaam is onmogelijk; een lid van het lichaam kan immers alleen bestaan in verbondenheid met het geheel. Deze eenheid behoort tot de identiteit van de gemeente. De eenheid is pneumatologisch van aard en christologisch van scopus ... De eenheid veronderstelt een meervoudigheid van leden, terwijl deze pluraliteit dienstbaar is aan de eenheid. Het 'una' van de kerk vraagt om het 'catholica', terwijl evenzeer het 'catholica' het 'una' veronderstelt. Deze twee kenmerken van de kerk zijn onlosmaaklijk met elkaar verbonden. Paulus maakt duidelijk dat eenheid en meervoudigheid elkaar veronderstellen, als zijde en keerzijde. (bl. 274-275)

Barth het daarop gewys dat kerk-wees 'n sirkel veronderstel. Hierdie artikel het ook op die 'narrated reality' van menswees gewys. Die werklikheid in die wêreld maak die sirkel 'n ellips. Die belydenis dat 'Jesus Christus die Kurios' is, behoort almal bymekaar te hou en te keer dat die sirkel, wat 'n ellips geword het, te veel uitrek of breek. Die uitleef van die belydenis beteken dat Jesus die lewe van Christusgelowiges beheer, dat die Gees van God en die Gees van Christus in gelowiges se harte woon (Rom 5:5; 8:9) - hoe verskillend hulle ook al mag wees (Rom 12:5). Omdat die één Gees in Christene se hart woon, leef hulle die evangelie van Jesus Christus uit. Soos die apostel Paulus sê: 'Ons is almal [Jood of Griek, Nederlander, Afrikaner of Zoeloe] deur die één Gees deurdrenk' (vgl. 1 Kor 12:13). Niemand kan bely dat Jesus Christus die Kurios is, sonder die Heilige Gees nie; en die Heilige Gees laat niemand Jesus vloek nie (1 Kor 12:3; 16:22).

Gerben Heitink (2007:141) het in sy boek, Een kerk met karakter: Tijd voor heroriëntatie, 'n subopskrif in sy hoofstuk 'De voortgang van de traditie', te wete, die Sache Jesu. In sy boek argumenteer hy dat 'n totale heroriëntasie oor kerkwees nodig is. Theuns Dreyer (2009:5 van 5) meen egter dat Heitink se ekklesiologiese model nog 'te veel vanuit die hoek van die kerk as instelling bedink word.'

Die gebrek aan eenheid bring die kerk se kerugma onder verdenking. ${ }^{9}$ Die gemeenskap van gelowiges behoort ooreen te stem met die band tussen die eenheid van die kerk en die verkondiging van die evangelie. In die Symbolum Apostolicum (kyk Ditton [1649] [1999] 2012) en in die Nicaeno-Constantinopolitanum (kyk Kelly [1958] 1982; Ayres 2006:85-100) word die volgende algemeen deur die kerk van die Weste én die Ooste bely: Eis mian, hagian, katholikēn kai apostolikēn ekklēsian (Grieks); Et unam, sanctam, catholicam et apostolicam ecclesiam (Latyn). In hierdie credo bely die kerk dat die gemeenskap van gelowiges één, heilig, apostolies en katoliek en/of algemeen is. Één, omdat die Heilige Gees in alle gelowiges woon; heilig, omdat gelowiges aan God behoort en aan God toegewy is; apostolies, omdat gelowiges

9. In hierdie afdeling van die studie word van die insigte van Van Aarde (2007) 'Versoenende verskeidenheid in kerkwees', Beskrywingspunt voorgelê aan die 68ste 'Versoenende verskeidenheid in kerkwees', Beskrywingspunt voorgelê aan die 68ste Algemene Kerkvergadering van die Nede
Argief (2007:9-14), gebruik gemaak. 
die Woord van God, soos betuig deur 'profete en apostels', as norm van die lewe beskou; katoliek en/of algemeen omdat gelowiges ten spyte van en te midde van verskeidenheid saam gemeenskap het met die Heilige Gees. Hierdie credo kom met die evangelie ooreen, en wel op 'n quia-wyse (kyk Meijering \& Van Winden 1983:8, n. 27).

Eenheid veronderstel algemeenheid maar nie noodwendig eenvormigheid nie. Eenheid kry vorm wanneer die gemeenskap van gelowiges tegelyk uitsluit (eksklusief is) en insluit (inklusief is). Die kerk is eksklusief, omdat die kerk bely dat Jesus Christus die Kurios is (kyk Boers 1970:450-456). Diegene wat nie so bely nie, is vir die kerk 'die Ander' en aan hulle word die evangelie verkondig en God se liefde betoon. Diegene wat wel so bely, bevind hulle in verskillende denominasionele tradisies (bv. Rooms-Katoliek of Protestant, Luthers of Calvinisties, Gereformeerd of Hervormd). Binne elke denominasie is daar verskillende teologiese oortuigings en is daar nie eenvormigheid nie. Die kerk is ook inklusief. ' $n$ Verskeidenheid van geestesgawes dien die eenheid van die gemeenskap van gelowiges. 'n Verskeidenheid van bedieninge breek nie die eenheid van die kerk nie, want die oorsprong van die gawes is die één Gees (vgl. Pelser 1990:1-18).

Die ekklēsia is 'n ruimte van versoenende verskeidenheid, want kerk-wees gee erkenning aan die werklikheid van verskeidenheid, maar roep ook die verskeidenheid op tot versoenende eenheid. Soos die ledemate van die liggaam van kop tot tone verskil, so verskil die lede van die liggaam van Christus van mekaar. Daar is verskille ten opsigte van geestesgawes (bedieninge) en ten opsigte van menswees. Die verskille in geestesgawes en bedieninge is nuttig vir die opbou van die geloofsgemeenskap - variasies wat saam dra tot voordeel van die geheel (pros to sumferon) (1 Kor 12:7): sommige lidmate is ampsdraers; party is helpers en ander dien op ' $n$ ander manier in die kerk. Daar is ook denominasies en gemeentes wat in hulle bedieningswyse van mekaar verskil as gevolg van topografie, demografie en kultuur. Almal is nie eners nie, maar dien die eenheid.

Soos bedieninge verskil, so verskil mense ook ten opsigte van verskeie ander sake. Die verskille in menswees bestaan breedweg uit geslagtelike en etniese identiteite (kyk Duling 2012:303-320; vgl. Denzey 2002:495; Hall 1997:38 43, 45, 47). Hierdie identiteite word sigbaar in sosiale rolle, binding aan 'n bepaalde grondgebied (land) en 'n bepaalde taal. Die identiteit van 'n sosio-kulturele groep kan verder gesien word in dit wat mense met mekaar deel, soos die waardes van hulle kultuur, gewoontes en historiese herinneringe. Identiteit het ook te doen met fisiese kenmerke wat kan ooreenkom, byvoorbeeld 'n groep se fenotipiese kenmerke soos die kleur van oë en vel, haarpatroon en gesigsvorm. Breedweg het hierdie diversiteit met sosiale identiteit te make. Dit hou verband met verskille ten opsigte van ouderdom, geslagtelikheid, nasionaliteit en ras. Sommige hiervan is meer vas (primordiaal) en ander meer veranderlik. Selfs dinge wat lyk of dit vas is, kan oor tyd heen verander as samelewings en demografie wissel. Niks wat geskape is, is onverganklik nie. Ten spyte van verskille behoort elke denominasie en plaaslike gemeente, waar ook al gesitueer, die eenheid van die gemeenskap van gelowiges op transdenominasionele wyse te reflekteer. Die eenheid word bewaar deur sowel eksklusief en inklusief in die bovermelde sin van die woord, te wees. Die kerk sluit nie uit op grond van verskille nie, maar wel op grond van die belydenis dat Jesus Christus die Kurios is.

In die versamelwerk, Facing the Other: The ethics of Emmanuel Levinas, wat onder redaksie van Seán Hand ([1996] 2011) uitgegee is, word op die kernaspek in die ekklesiologie gefokus, naamlik dat die etiese dimensie onlosmaaklik van beide ontologie en epistemologie waardeer behoort te word. As die etiese konsekwensie van hierdie ontologie en epistemologie egter nie tot die ekklesiologie deurgetrek word nie, is die mees sentrale saak, naamlik om die Ander te akkommodeer, vermy. Die Sweedse filosoof van Uppsala, Zlatan Filipovic (2011:58), reflekteer op die tipiese Westerse uitdrukking van goeie maniere: 'After you, sir!' So fokus hy op die kern van Levinas se appèl om die Ander te akkommodeer. Wanneer ontologie primêr word, 'ensures and solidifies' dit die mens se eksistensie, maar dit regverdig nie die 'concern and fear for the other person' nie (Filipovic 2011:58). Indien etiek aan epistemologie ondergeskik gestel word, is die gevolg volgens Filipovic (2011):

Far from innocent idealism or naiveté of premature consciousness, the concern for the other person for Levinas, and contrary to the entire tradition of Western philosophy, is what constitutes our subjectivity. One is a subject only and insofar as one is awakened or 'sobered up' to responsibility for the other person. The very identity, what makes me unique and irreplaceable in Levinas, is precisely the fact that no one can answer or respond to the distress of the other in my stead. This is what consigns me to my identity, the impossibility to shirk my responsibility without blame. My very enterprise in being a social subject is to be for the other person. 'Before the Other (Autrui)', says Levinas, 'the $\mathrm{I}$ is infinitely responsible. The Other is the poor and destitute one, and nothing which concerns this Stranger can leave the I indifferent.' Indeed, he says, it is what is 'presupposed in all human relationships. If it were not that, we would not even say, before opening a door, 'After you, sir!' It is an original 'After you, sir!', the original welcome that establishes hospitality and human solidarity at the very beginning of history. 'After you sir', under all its quotidian significations, reveals the depth of the originary call to Goodness where the other person precedes my freedom and counts more than myself. (bl. 58-59)

Aan die hand van Paulus (1 Kor 12:22-26) kan die konsekwensie van Trinitariese ekklesiologie - in terme van 'n ontologiese en epistemologiese refleksie - as die Goddelike etiek agter kerk-wees beskryf word. In die ekklēsia word groter beskerming aan die 'ongewenstes' gegee deur die Ander met ongekwalifiseerde groot respek in die eenheid van die liggaam te akkommodeer. Die gevolg is: as die een ly, ly die ander saam; as die een geëer word, is die ander saam bly.

Kerk-wees as ellips se twee grense is enersyds die 'gelowige-relasie-God' en andersyds die relasie uitgedruk in die begrip 'genealogie'. Relasies wat in 'genealogie' manifesteer, het geen selfstandigheid wat die relasie met 
God kan oorwoeker nie. Dié nota ecclesiae is die liefde van God en die liefde vir God. Hierdie agapē is koinōnia. Wanneer genealogie 'n selfstandige waarde in die absolute sin van die woord kry, het die ellips alreeds so ver gerek dat dit gebreek het. Kerk-wees as ellips, waarin die waarde van menslike kultuur besef word sonder om die prioriteit van die heil in Christus prys te gee, sal vir die Afrikaanssprekende kerke 'n volledige transendering van 'nasie-kerk' kan wees. Sodoende kan ook die Afrikaanssprekende kerk 'n uitsonderlike bydrae lewer om sosiale kohesie in postapartheid Suid-Afrika te help vestig.

\section{Erkenning \\ Mededingende belange}

Die outeur verklaar dat sy geen finansiële of persoonlike verbintenis het met enige party wat haar nadelig kon beïnvloed in die skryf van hierdie artikel nie.

\section{Literatuurverwysings}

Abizadeh, A., 2004, 'Historical truth, national myths and liberal democracy: On the coherence of liberal nationalism', The Journal of Political Philosophy 12(3), 291-313. http://dx.doi.org/10.1111/j.1467-9760.2004.00201.x

Anderson, B., 1983, Imagined communities: Reflections on the origin and spread of Nationalism, Verso, London.

Argief-Jaarboek vir Suid-Afrikaanse geskiedenis/Archives year book for South African History, 1955, Perskor, Doornfontein.

Ashcroft, B., Griffiths, G. \& Tiffin, H. (eds.), 1995, The postcolonial studies reader, Routledge, London.

Ayres, L., 2006, Nicaea and its legacy, Oxford University Press, Oxford.

Barnes, G., 2010, Napoleon Bonaparte: The background, strategies, tactics, and battlefield experiences of the greatest commanders of history, Osprey Publishing, Oxford.

Barth, K., [1935] 1964, Credo: Hauptprobleme der Dogmatik dargestellt im Anschluß an das Apostolische Glaubensbekenntnis, 16 Vorlesungen, gehalten an der Universität Utrecht im Februar und März 1935, 3. Aufl., Chr. Kaiser Verlag, München.

Berkhof, H., 1962a, De katholiciteit der kerk, Callenbach, Nijkerk.

Berkhof, H., 1962b, 'Tweërlei Ekklesiologie, Kerk \& Theologie 13(3), 145-148.

Bigler, R., 1972, The politics of German Protestantism: The rise of the Protestant elite in Prussia 1815-1848, University of California Press, Berkeley, CA.

Boers, H., 1970, 'Jesus and the Christian faith: New Testament Christology since Bousset's Kyrios Christos', Journal of Biblical Literature 89(4), 450-456. http://dx.doi.org/10.2307/3263451

Boesak, A.A. \& De Young, C.P., 2012, Radical reconciliation: Beyond political pietism and Christian quietism, Orbis Books, New York, NY.

Breuilly, J., 2002, 'Nationalismus als kulturelle Konstruktion', in J. Echternkamp \& S.O. Müller (eds.), Die Politik der Nation: Deutscher Nationalismus in Krieg und Krisen 1760-1790, pp. 200-250, R. Oldenburg, München.

Brink, A.P., 1987, Vertelkunde: 'n Inleiding tot die lees van verhalende tekste, Academia, Kaapstad.

Brown, S.J. \& Tackett, T., 2006, The Cambridge history of Christianity, vol. 7, Enlightenment, Reawakening and Revolution 1660-1815, Cambridge University Press, Cambridge.

De Groot, K., 2005, 'Pleitdooi voor een uitnodigende kerk', Theologisch 2(3), 11-19.

De Reuver, R., 2004, Eén kerk in meervoud: een theologisch onderzoek naar de ecclesiologische waarde van pluraliteit, Boekencentrum, Zoetermeer.

Denzey, N., 2002, 'The limits of ethnic categories', in A.J. Balsi, J. Duhaime, J. \& P.A.Turcottr, (eds.), Handbook of early Christianity, pp. 489-507, Altamira, Walnut Creek, CA.

Dilthey, W., 1936, 'Zur preussischen Geschichte: Schleiermachers politische Gesinnung und Wirksamkeit. Die Reorganisatoren des preussischen Staates. Das allgemeine Landrecht', in E. Weniger (Hrsg.), Gesammelte Schriften, Vandenhoeck \& Ruprecht, Göttingen.

Ditton, G., [1649] [1999] 2012, Symbolum apostolicum, Thomas Harper Publishing, London, electronic reproduction: University of Michigan Library, Ann Arbor, 2012, digital version of Thomason Tracts, viewed 25 February 2014, from http:// gateway.proquest.com/openurl?ctx_ver=Z39.88-2003\&res_id=xri:eebo\&rft_val_ $\mathrm{fmt}=\& \mathrm{rft}$ id =xri:eebo:image:16307

Dreyer, T.F.J., 2009, "n Kerk met karakter: Die perspektief van Gerben Heitink', HTS Teologiese Studies/Theological Studies 65(1), Art. \#315, 5 pages, http://dx.doi. org10.4102/hts.v65i.315
Duling, D.C., 2012, A marginal scribe: Studies in the Gospel of Matthew in a socialscientific perspective, Cascade Books, Eugene, OR.

Dürr, J., 1947, Sendende und werdende Kirche in der Missionstheologie Gustav Warnecks, Buchdruckerei F. Graf-Lehman, Bern.

Elzinga, D.J., De Lange, R. \& Hoogers, H.G., 2006, Van der Pot-Donner, Handboek van het Nederlandse staatsrecht, Kluwer, Deventer.

Filipovic, Z., 2011, 'Introduction to Emmanuel Levinas: "After you, sir!"', Die sweed 105(1), 58-73, viewed 21 August 2012, from http://www.ojs.ub.gu.se/ojs/index. $\mathrm{php/modernasprak/article/viewFile/667/618}$

Genette, G., [1972] 1980, Narrative discourse: An essay in method, transl. J.E. Lewin, Cornell University Press, Ithaca, NY.

Graham, E., 2002, 'Liberal theology and transformative pedagogy: A response to Peter Hodgson', in M.D. Chapman (ed.), The future of liberal theology, pp. 129-138, Ashgate, Aldershot.

Habermas, J., 2001, Glauben und Wissen: Friedenspreis des Deutschen Buchhandels, Suherkamp, Frankfurt am Main.

Hall, J.M., 1997, Ethnic identity in Greek antiquity, Cambridge University Press, Cambridge. http://dx.doi.org/10.1017/CBO9780511605642

Hand, S. (ed.), [1996] 2011, Facing the Other: The ethics of Emmanuel Levinas, Taylor \& Francis, London.

Heitink, G., 2007, Een kerk met karakter: Tijd voor heroriëntatie, Kok, Kampen.

Hoekendijk, J.C., 1948, 'Kerk en volk in die Duitse zendingwetenschap', Dtheol dissertatie, Rijksuniversiteit van Utrecht, Amsterdam.

Howard, M., 2001, Franco-Prussian war: The German invasion of France 1870-1871, rev. edn., Routledge, London.

Jeanrond, W.G., 1992, 'From resistance to liberation theology: German theologians and the non/resistance to the national socialist regime', The Journal of Modern History 65, 187-203. http://dx.doi.org/10.1086/244436

Jonker, W.D., 1989, 'Die pluriformiteitsleer van Abraham Kuyper: Teologiese onderbou vir die konsep van aparte kerke vir aparte volksgroepe', In die Skriflig/In Luce Verb 23, 12-23. http://dx.doi.org/10.4102/ids.v23i91.832

Kedourie, E., 1960, Nationalism, Hutchinson, London.

Kelly, J.N.D., [1958] 1982, Early Christian doctrines, 5th rev. edn., Longman Publishing, Harlow.

Koopman, N., 2008, 'The Confession of Belhar 1986: A guide for justice, reconciliation and unity', Journal of Reformed Theology 2(1), 28-39. http://dx.doi. org/10.1163/156973108X272630

Lämmert, E., [1955] 1972, Bauformen des Erzählens, 5. Aufl., Metzlersche Verlagsbuchhandlung, Stuttgart.

Leersen, S.J., 2006, National thought in Europe: A cultural history, Amsterdam University Press, Amsterdam.

Lenski, G., Nolan, P. \& Lenski, J. [1970] 1995, Human societies: An introduction to macrosociology, 7th edn., McGraw-Hill, New York, NY.

Lowenthal, D., 1991, 'British National Identity and the English Landscape', Rural History 2, 205-230. http://dx.doi.org/10.1017/S0956793300002764

Meijering, E.P. \& Van Winden, J.C.M., 1982, Hilary of Poitiers on the Trinity: De Trinitate I, 1-19, Brill, Leiden.

Moore, S.D., 2000, 'Postcolonialism', in A.K.M. Adam (ed.), Handbook of postmodern Biblical interpretation, pp. 182-188, Chalice Press, St. Louis, MO.

Moxnes, H., 2012, Jesus and the rise of nationalism, I.B.Tauris \& Co., London.

Nederduitsch Hervormde Kerk van Afrika (NHKA), Kommissie van die Algemene Kerkvergadering, 2007, 'Agenda van die 68ste Algemene Kerkvergadering', Kerkargief, Pretoria.

Nord, P.G., 1995, The republican moment: Struggles for democracy in nineteenthcentury France, Harvard University Press, Cambridge, MA

Oldenhuis, F.T., Brouwer, J.G., Wegerif, D.N.R. \& Keijzer, F.E. (reds.), 2007, 'Schurende relaties tussen recht en religie', Instituut voor Integratie en sociale weerbaarheid, Rijksuniversiteit Groningen.

Özkirimli, U., 2005, Contemporary debates on nationalism: A critical engagement, Palgrave MacMillan, New York, NY.

Pelser, G.M.M., 1990, 'Die bedieninge in die Nuwe Testament: 'n Ondersoek na historiese wording en prinsipiële regverdigbaarheid', Praktiese Teologie in Suid-Afrika 5, 1-18.

Peukert, D., 1987, Inside Nazi Germany: Conformity, opposition and racism in everyday life, Batsford, London.

Reed, H. 2004, s.v. 'Friedrich Daniel Ernst Schleiermacher (1768-1834)', The Boston Collaborative Encyclopedia of Modern Western Theology, viewed 06 September 2012, from http://www.people.bu.edu/wwildman/bce/mwt_themes_470_ schleiermacher.htm

Renan, E., 1996, Qu'est-ce qu'une nation? What is a Nation?, transl. W.R. Taylory, introduction by Charles Taylor, Tapir, Toronto.

Santing-Wubs, A.H., 2002, Kerken in geding: De burgerlijke rechter en de kerkelijke geschillen, Boom Juridische uitgevers, Den Haag.

Schama, P., 1977, Patriots and liberators: Revolution in the Netherlands 1780-1813, Alfred Knopf, New York, NY.

Schama, S., 1995, Landscape and Memory, Harper Collins, London.

Schleiermacher, F.D.E., 1864, 'Das Leben Jesu', in K.A. Rütenik (ed.), Sämmtliche Werke 1(6), Georg Reimer, Berlin. 
Schleiermacher, F.D.E., 1890, 'A Nations' duty in a war for freedom', in Selected Sermons of Schleiermacher, transl. Mary F. Wilson, Hodder and Stoughton, London.

Schrag, C.O., 1997, The self after postmodernity, Yale University Press, New Haven, CT. Smith, G. A., [1894] 1910, Historical geography of the Holy Land, Hodder and Stoughton, London.

Snyder, H., 2002, Decoding the church: mapping the DNA of Christ's Body, Bake Books, Grand Rapids, MI.

Spencer, V.A., 2012, Herder's political thought: A study on language, culture and community, University of Toronto Press, Toronto.

Strauß, D.F., 1835, Das Leben Jesu, F.A. Brockhaus, Leipzig.

Strauß, D.F., 1864, Das Leben Jesu für das deutsche Volk, 2. Aufl., F.A. Brockhaus, Leipzig.

Strauß, D.F., 1865, Der Christus des Glaubens und der Jesus der Geschichte, Franz Duncker, Berlin.

Ten Hooven, M. \& de Wit, T., 2006, Ongewenste goden: De publieke rol van religie in Nederland, Sun Uitgeverij, Amsterdam.
Tosh, J., Hagemann, K., \& Dudink, S., 2004, Masculinities in politcs and war: Gendering modern History, Manchester University Press, Manchester.

Towell, J.E., 2003, 'The "rise and progress" of Anglo-Saxonism and English national identity: Old English literature in the nineteenth century', doctoral dissertation, Wayne State University, viewed 04 September 2012, from http://digitalcommons. wayne.edu/dissertations/AAI3086478

Van Aarde, A.G., 2009, 'Theological trends in our postsecular age', Verbum et Ecclesia 30(3), Art. \#178, 8 pages. http://dx.doi.org/10.4102/ve.v30i3.178

Van Huyssteen, J.W., 1999, The shaping of rationality: Toward interdisciplinarity in theology and science, Eerdmans, Grand Rapids, MI.

Van Wyk, T., 2013a, 'Om saam te weet en dan te luister: Edward Schillebeeckx se begrip Deus Humanissimus as die kerk se gewete', HTS Teologiese Studies/ Theological Studies 69(1), Art. \#1983, 10 pages. http://dx.doi.org/10.4102/hts. v69i1.1983

Van Wyk, T., 2013b, 'Kerk as heterotopiese ruimte: 'n Trinitariese ekklesiologiese model vir die derde millennium', PhD-proekskrif, Departement Dogmatiek en Christelike Etiek, Universiteit van Pretoria.

Young, R.C., 1996, Torn halves: Political conflict in literary and cultural theory Manchester University Press, Manchester. 